\title{
The Influence of Demographic Factors on Reading Comprehension amongst Undergraduate Students in Benue State University Makurdi.
}

\author{
${ }^{1}$ Tor-Akwer, Helen F., ${ }^{2}$ Chorun, Matthew Terfa (CLN) \\ ${ }^{1,2}$ Francis Sulemanu Idachaba Library, University of Agriculture, Makurdi.
}

\begin{abstract}
Reading habits and comprehension has featured in scholarly publication in the past years. And this particular study sees how demographic factors can be a determinant of reading habits and comprehension of undergraduate students in their use of library resources. However, the degree of commitment of students to reading habits and comprehension has no joint effect on demographic factors; the study takes a cursory look at how demographic factors are determinant of reading habits and comprehension of undergraduate students. The study adopted the descriptive research design, purposive sampling technique also used with the sample size of five hundred (500) undergraduate students taken from some selected departments, using all levels of study. Three (3) instruments synchronised into a questionnaire titled Demographic factors as determinant of Reading Habits of Undergraduate Students Questionnaire (DFDRHUS) was used to elicit the needed information. The Statistical Package for Social Sciences (SPSS) software and the use of miltivariate and univariate statistical tool were used. Descriptive statistics (gender, age, marital status, level of study and occupation) on reading and comprehension was the bane of analysis. The study revealed that Gender, Age, Marital status, Level of study and Occupation are good predictors of Reading Habit of Students.

Conclusions are also drawn and recommendations suggested are based on the analysis and strength of the hypothesis. The findings have implication on students, stakeholders and government in the bid towards good reading habits and comprehension of undergraduate students in the use of library resource
\end{abstract}

\section{Introduction}

Reading and comprehension are intertwined as there can be no comprehension without effective reading ability. Reading basically is concerned with attaching meanings to the writing thoughts or ideals of a given author. The ability to deduce relevant meanings from the ideas of the author without deviating from his/her intention can be regarded as comprehension. As a developmental skill, reading ability It is once said that a child's mind was tabula rasa, meaning that a new born child's mind is as blank as a sheet of paper or a clean slate, which means if a new born baby's mind is like a blank slate which can be shaped into whatever one desires by training the child how to read and comprehend. In line with this Aina, Ogungbeni, Adigun and Ogundipe (2011) of the opinions that reading is a skill that must be nurtured from a child's earliest years and the habit of reading should begin at an early stage and should be imbibed throughout one's lifetime. Ability to read and write involves training of a child right from the cradle. Before a child can be able to read and comprehend, it involves a lot of exercise, right from kindergarten to primary where a child would be taught how to recognize letters, figure and spelling then how to read.

The ability to read is a crucial skill for information retrieval A nation whose young and old wallow in banalities, showing little quality interest to useful information and education is obviously doomed. The entire process of education and the development of literacy depend largely on printed words and reading is the crucial means through which one develops this literacy and knowledge about his environment. Issa and Aliyu (2012) opined that a creative and pragmatic education involves the habit of personal investigation. The art of personal investigation requires self-study to be followed by self-thinking and analysis. Self-study, otherwise referred to as reading at one's own accord, requires a habit.

One way of getting information is to read. In the words of the Reading Association of Nigeria \& International Reading Association, "Reading is power! Read a book today! Reading maketh a man! Teach a child to read ---- and you have made a king!" This assertion indicates the place of reading in the general development of man and his society. It places reading in the top rung of the ladder of human development.

Reading is one of the fundamental building blocks of learning. Becoming a skilled and adaptable reader enhances the chances of success at school and beyond. Reading is not just for school, it is for life. Reading in all its variety is vital to being better informed, have a better understanding of oneself as well as others. It makes man to be a thoughtful and constructive contributor to a democratic and cohesive society. 


\section{Literature Review}

The definition of reading has gone through many changes. In the past, reading simply meant to extract visual information from any given codes or systems. However, thereafter, reading became much more complex and involved the understanding of a whole text composed of written signs. It is "an active attempt on the part of reader to understand a writer's message." Lone (2011) describes reading as been the passion of the greatest personalities of all times. Humans have been reading since ages, and thus, words of knowledge have been passed on through generations. The reading habit influences in the promotion of one's personal development in particular and social progress in general. Regular and systematic reading sharpens the intellect, refines the emotions, elevates tastes and provides perspectives for one's living; and thereby prepares a person for an effective participation in the social, religious, cultural and political life. The individual who reads well has a means for widening mental horizons and for multiplying opportunities of success. Reading is a vital factor affecting intellectual and emotional growth. Sir Richard Steele has logically quoted, "Reading is to the mind what exercise is to body" (Lone, 2011).

Reading habit is having a strong desire to read everything 'readable' every time and everywhere. In this world, hardly anyone denies the significance attached to reading as the most generally needed skill in EAP (English for Academic Purposes) worldwide and as one of the best ways to remain up-to-date and well informed. The understanding of reading that includes both decoding and comprehending. If a reader can both decode and comprehend the printed word, she/he has attained a skill in reading that offers the most personal fulfillment and future success. As such, reading which involves both proficient decoding and skilful comprehension is the ultimate goal of reading instruction. Reading comprehension is much more than the ability to read individual words and know what those words mean. To comprehend what one reads is to understand the meaningful message sent by the author. Aina etal. (2011) says that comprehension is at the centre of reading. Reading comprehension includes all of the processes related to deriving meaning from written language (including books and other forms of written language) and constructing meaning from written language. "Deriving meaning" indicates that there is meaning in texts and that meaning needs to be understood. "Constructing meaning" indicates that often readers go beyond the meaning explicitly contained in the text and add to that meaning based on their own experience and their ability to infer additional or deeper meaning. Reading comprehension can be understood as the process through which the recognized words are transformed into a meaningful idea. Reading comprehension is an important goal of the reading process and comprehension is influenced by several factors.

It is a simple truth also that one cannot write without reading. Reading is an inherent part of the writing process and it is the basis of our system for monitoring the meaning we construct when we write. The ability to read is one determiner of students' success or failure. They must form the habit of reading to perform well in all subjects. A good reader has a better opportunity for greater achievement Kolawole (2009) since reading is the students most important tool for learning, they need to use this tool with precision and at a rate appropriate to the task of learning and coping with the rigour of academic activities on their various campuses. Kolawole (2009) Higher education is Nigeria encompasses various institutions such as universities, polytechnics and colleges of education and many others where reading is emphasized. The advancement or progress to this level is therefore dependent on success at the secondary school level. Students of higher institution poor academic performance can be traced to lack of reading and or reading comprehension and it is not far from the truth that the undergraduate student who find difficulties in reading comprehension might have developed that right from primary school, in essence, reading comprehension at elementary level is crucial and it serve as corner stone or educational foundation of a child, once is been affected the whole academic achievement is totally in doom.

\section{Demographic Factors and their influence on reading comprehension}

The demographic factors and life experiences associated with age-related changes in comprehension (including skill acquisition and development, decline, maintenance, compensation, and improvement) as well as understanding the epidemiology of age-related decline in comprehension. Bray et al (2004) noted that college students' literacy, which includes reading comprehension and attitude toward literacy activities, fluctuated depending on the background variables such as race, gender, and prior literacy activities. Amongst these trends that affect reading habits are age and gender; specifically, that preferences change as children get older and boys and girls may exercise different reading habits. Also one notable connection is the relatively poor literacy performance of boys compared to girls both in school and on standardized achievement tests. Concern over this "gender gap" has prompted much research. Studies attempting to explain the discrepancy between girls' and boys' academic achievement often look at reading preferences; specifically, if there is a difference in the reading habits and choices of boys and girls. Additionally, studies have looked at how these habits change over time particularly, as the gap widens around middle school.

Sturm (2003) suggested that age and gender do indeed affect reading preferences and these preferences change as a child grows older. He asserts further that girls enjoy reading greater than boys and boys tend to hold 
more negative attitudes towards reading than girls. Hopper (2005) depicts that $(67 \%)$ of girls were reading compared with (54\%) of boys.

Hill Strategies Research (2008) carried out research on Canadians on demographic factors in book reading and submits that overall, book reading appears to be an activity that is enjoyed fairly equally by many groups of. The only demographic factors that have a substantial impact on book reading rates are education and sex. Hill Strategies Research (2008) further expresses that the book reading rate for individuals whose mothers obtained a university degree (79\%) is 1.2 times the rate for individuals whose mothers did not obtain a high school diploma (65\%). It is interesting to note that the ratio (1.2) is lower than the own-education ratio (1.5) largely because of the relatively high book reading rate for individuals whose mothers received less than a high school education (65\%). Women are much more likely than men to read as a leisure activity. In $2005,75 \%$ of women read a book, compared to $58 \%$ of men. The female reading rate is 1.3 times the male rate. Also Demographic factors that have either a limited or no impact on book reading include age, income, presence of children, residing in an urban area, language, country of birth and activity limitations.

From the review above it is clear that the core of the attitude-influence model explains a reader's whole attitude toward reading (i.e., prevailing feelings and evaluative beliefs about reading and action readiness for reading) will influence the intention to read, in turn influencing reading behaviour.

\section{Methodology}

The study adopted the descriptive research design. The population of study consisted of undergraduate students of faculties of social science, arts and education from Benue state university, makurdi. Purposive sampling technique was used to select 500 undergraduate students out of 2216.A self-developed questionnaire tagged Demographic factors as determinant of Reading Habits of undergraduate students' questionnaire (DFDRHUS) was used to collect data. Two research assistants helped with the administration of questionnaire. A total of 450 undergraduate students out of 500 sampled responded and the copies of their questionnaire were found valid for analysis given a response rate of $84.3 \%$

\section{Distribution of the respondents by Sex}

\section{Results}

\begin{tabular}{|l|l|l|}
\hline Sex & Frequency & Percentage \\
\hline Male & 277 & 61.6 \\
Female & 173 & 38.4 \\
Total & 450 & 100.0 \\
\hline
\end{tabular}

Table 1 above shows that $277(61.6 \%)$ of the respondents were males while their female Counterparts were $173(38.4 \%)$.

\section{Distribution of the respondents by Age}

\begin{tabular}{|l|l|l|}
\hline Age & Frequency & Percentage \\
\hline $10-19$ years & 44 & 9.8 \\
$20-29$ years & 361 & 80.2 \\
$30-39$ years & 35 & 7.8 \\
$40-49$ years & 9 & 2.0 \\
Above 50 years & 1 & .2 \\
Total & 450 & 100.0 \\
& & \\
\hline
\end{tabular}

Table2 above shows that $44(9.8 \%)$ of the respondents were aged 10-19 years, 361(80.2\%) were aged 20-29 years, $35(7.8 \%)$ were aged $30-39$ years, $9(2.0 \%)$ were aged $40-49$ years, while $1(.2 \%)$ was above 50 years.

Distribution of the respondents by Marital Status

\begin{tabular}{|l|l|l|}
\hline Marital Status & Frequency & Percentage \\
\hline Single & 387 & 86.0 \\
Married & 54 & 12.0 \\
Divorced & 3 & .7 \\
Widowed & 6 & 1.3 \\
Total & 450 & 100.0 \\
\hline
\end{tabular}

Table. 3 above shows that $387(86.0 \%)$ of the respondents were Single, 54(12.0\%) were Married, 3(.7\%) were Divorced while 6(1.3\%) were Widowed. 
Distribution of the respondents by Level of Study

\begin{tabular}{|l|l|l|}
\hline Level of Study & Frequency & Percentage \\
\hline 100 & 11 & 2.4 \\
200 & 163 & 36.2 \\
300 & 235 & 52.2 \\
400 & 41 & 9.1 \\
Total & 450 & 100.0 \\
\hline
\end{tabular}

Table.4 above shows that $11(2.4 \%)$ of the respondents were in 100 levels, $163(36.2 \%)$ were in 200 levels, $235(52.2 \%)$ were in 300 levels, while $41(9.1 \%)$ were in 400 levels.

\section{Distribution of the respondents by Occupation}

\begin{tabular}{|l|l|l|}
\hline Occupation & Frequency & Percentage \\
\hline No response & 30 & 6.7 \\
Farmer & 8 & 1.8 \\
Trader & 10 & 2.2 \\
Civil servant & 12 & 2.7 \\
Artisans & 5 & 1.1 \\
Police, Soldier & 5 & 1.1 \\
Students, housewife, pastor & 380 & 84.4 \\
Total & 450 & 100.0 \\
\hline
\end{tabular}

Table. 5 above shows that $30(6.7 \%)$ of the respondents did not respond, $8(1.8 \%)$ were Farmers, $10(2.2 \%)$ were Traders, 12(2.7\%) were Civil servants, 5(1.1\%) were Artisans, 5(1.1\%) were Policemen, Soldiers while $380(84.4 \%)$ were Students.

Hypothesis 1: There is no significant joint effect of Independent variables of (Gender, Age, Marital status, Level of study and Occupation) on Reading Habit of Students.

\section{Testing of the Null Hypothesis}

Table 6a: $\quad$ Regression showing the joint effect of Independent variables of (Gender, Age, Marital status, Level of study and Occupation) on Reading Habit of Students.

\begin{tabular}{|l|l|l|l|l|l|}
\hline Model & $\begin{array}{l}\text { Sum of } \\
\text { Squares }\end{array}$ & DF & Mean Square & F & Sig. \\
\hline Regression & 395.235 & 5 & 79.047 & 3.427 & .005 \\
Residual & 10242.376 & 444 & 23.068 & & \\
Total & 10637.611 & 449 & & & \\
\hline
\end{tabular}

$\mathrm{R}=.193$

$\mathrm{R}^{2}=.037$

Adj $R^{2}=.026$

It was shown in the table above that the joint effect of independent variables (Gender, Age, Marital status, Level of study and Occupation) on Reading Habit of Students was significant $(\mathrm{F}(5,444)=3.427 ; \mathrm{R}=$ $.193, \mathrm{R}^{2}=.037$, Adj. $\left.\mathrm{R}^{2}=.026 ; \mathrm{P}<.05\right)$.

The independent/predictor variables jointly accounted for a variation of about 4\%.It is also shown in the results that Gender, Age, Marital status, Level of study and Occupation are good predictors of Reading Habit of Students.

Null hypothesis is rejected.

Table 6b: Table showing the relative contributions of each of the Independent variables (Gender, Age, Marital status, Level of study and Occupation) on Reading Habit of Students.

\begin{tabular}{|l|l|l|l|l|l|}
\hline \multirow{2}{*}{ Model } & \multicolumn{2}{|l|}{ Unstandardized Coefficient } & $\begin{array}{l}\text { Standardized } \\
\text { Coefficient }\end{array}$ & T & Sig. \\
\cline { 2 - 4 } & $\mathrm{B}$ & Std. Error & $\begin{array}{l}\text { Beta } \\
\text { Contribution }\end{array}$ & & \\
\hline (Constant) & 43.990 & 1.596 & & 27.563 & .000 \\
Gender & .302 & .468 & .030 & .646 & .518 \\
Age & .994 & .455 & .107 & 2.185 & .029 \\
Marital status & -1.336 & .504 & -.134 & -2.647 & .008 \\
Level of study & -.990 & .342 & -.136 & -2.892 & .004 \\
Occupation & $3.208 \mathrm{E}-02$ & .086 & .018 & .372 & .710 \\
\hline
\end{tabular}

The result above shows the relative contribution of each of the independent variables on the dependent: Gender $(\beta=.030, \mathrm{P}>.05)$, Age $(\beta=.107, \mathrm{P}<.05)$, Marital status $(\beta=-.134, \mathrm{P}<.05)$, Level of study $(\beta=-.136, \mathrm{P}$ $<.05)$ and Occupation $(\beta=.018, \mathrm{P}>.05)$.

Hence, while Age, Marital status and Level of study were significant, Gender and Occupation were not. 
Table 6c: Correlation matrix showing the relationship between Reading Habit of Students and Gender, Age, Marital Status, Level of study and Occupation.

\begin{tabular}{|l|l|l|l|l|l|l|l|l|}
\hline & $\begin{array}{l}\text { Reading } \\
\text { Habit }\end{array}$ & Gender & Age & $\begin{array}{l}\text { Marital } \\
\text { Status }\end{array}$ & $\begin{array}{l}\text { Level of } \\
\text { Study }\end{array}$ & Occupation & $\begin{array}{l}\text { Mean } \\
\text { Dev. }\end{array}$ \\
\hline Reading Habit & 1 & & & & & & 42.46 & 4.87 \\
\hline Gender & .033 & 1 & & & & & 0.49 \\
\hline Age & .058 & .003 & 1 & & & & 2.38 \\
\hline Marital Status & $-.098^{*}$ & -.028 & $.304^{* *}$ & 1 & & & 0.52 \\
\hline Level of Study & $-.120^{*}$ & .023 & .050 & -.062 & 1 & & 0.49 \\
\hline Occupation & .027 & $.100^{*}$ & $-.101^{*}$ & $-.262^{* *}$ & $.136^{* *}$ & 1 & 2.17 \\
\hline
\end{tabular}

** Sig. at .01 level, ${ }^{*}$ Sig. at .05 level

Results above show that while there were negative significant relationships between Reading Habit of Students and Marital Status( $(\mathrm{r}=-.098 *, \mathrm{P}(.037)>.05)$ and Level of Study $(\mathrm{r}=-.120 *, \mathrm{P}(.011)>.05)$, there were no significant relationships between Reading Habit of Students and Gender $(\mathrm{r}=.033, \mathrm{P}(.033)>.05)$, Age $(\mathrm{r}=.058$, $\mathrm{P}(.219)>.05)$ and Occupation $(\mathrm{r}=.027, \mathrm{P}(.569)>.05)$.

Hypothesis 2: There is no significant joint effect of Independent variables of (Gender, Age, Marital status, Level of study and Occupation) on Reading Comprehension.

Table 6d: Regression showing the joint effect of Independent variables of (Gender, Age, Marital status, Level of study and Occupation) on Reading Comprehension.

\begin{tabular}{|l|l|l|l|l|l|}
\hline Model & Sum of Squares & DF & Mean Square & F & Sig. \\
\hline Regression & 148.568 & 5 & 29.714 & .969 & .436 \\
Residual & 13613.290 & 444 & 30.661 & & \\
Total & 13761.858 & 449 & & & \\
\hline
\end{tabular}

$\mathrm{R}=.104$

$\mathrm{R}^{2}=.011$

Adj $\mathrm{R}^{2}=.000$

It was shown in the table above that the joint effect of independent variables (Gender, Age, Marital status, Level of study and Occupation) on Reading Comprehension was not found significant $(\mathrm{F}(5,444)=.969$; $\mathrm{R}=.104, \mathrm{R}^{2}=.011$, Adj. $\left.\mathrm{R}^{2}=.000 ; \mathrm{P}>.05\right)$. The independent/predictor variables jointly accounted for a variation of about $1 \%$.It is also shown in the results that Gender, Age, Marital status, Level of study and Occupation are not good predictors of Reading Comprehension in the study.

\section{Null hypothesis is accepted.}

Table 6e: $\quad$ Table showing the relative contributions of each of the Independent variables (Gender, Age, Marital status, Level of study and Occupation) on Reading Comprehension.

\begin{tabular}{|c|c|c|c|c|c|}
\hline \multirow[t]{2}{*}{ Model } & \multicolumn{2}{|c|}{ Unstandardized Coefficient } & Standardize & \multirow[t]{2}{*}{$\mathrm{T}$} & \multirow[t]{2}{*}{ Sig. } \\
\hline & B & Std. Error & Beta Contribution & & \\
\hline (Constant) & 32.373 & 1.840 & & 17.594 & .000 \\
\hline Gender & $-6.123 \mathrm{E}-02$ & .539 & -.005 & -.114 & .910 \\
\hline Age & .139 & .524 & 013 & .265 & .791 \\
\hline Marital status & $2.084 \mathrm{E}-02$ & .582 & .002 & .036 & .971 \\
\hline Level of study & -.678 & .395 & -.082 & -1.717 & .087 \\
\hline Occupation & -.101 & .099 & -.050 & -1.018 & .309 \\
\hline
\end{tabular}

The result above shows the relative contribution of each of the independent variables on the dependent: Gender $(\beta=-.005, \mathrm{P}>.05)$, Age $(\beta=.013, \mathrm{P}>.05)$, Marital status $(\beta=.002, \mathrm{P}>.05)$, Level of study $(\beta=-.082, \mathrm{P}$ $>.05)$ and Occupation $(\beta=-.050, \mathrm{P}>.05)$. None of the independent variables was found significant in the study.

Table 6f: Correlation matrix showing the relationship between Reading Comprehension of Students and Gender, Age, Marital Status, Level of study and Occupation.

\begin{tabular}{|c|c|c|c|c|c|c|c|c|}
\hline & $\begin{array}{l}\text { Reading } \\
\text { Comprehension }\end{array}$ & Gender & Age & $\begin{array}{l}\text { Marital } \\
\text { Status }\end{array}$ & $\begin{array}{l}\text { Level of } \\
\text { Study }\end{array}$ & Occupation & Mean & Std. Dev. \\
\hline $\begin{array}{l}\text { Reading } \\
\text { Comprehension }\end{array}$ & 1 & & & & & & 29.98 & 5.54 \\
\hline Gender & -.012 & 1 & & & & & 1.38 & 0.49 \\
\hline Age & .015 & .003 & 1 & & & & 2.03 & 0.52 \\
\hline Marital Status & .024 & -.028 & $.304 * *$ & 1 & & & 1.17 & 0.49 \\
\hline Level of Study & -.089 & .023 & .050 & -.062 & 1 & & 2.68 & 0.67 \\
\hline Occupation & -.064 & $.100 * *$ & $-.101 *$ & $-.262 * *$ & $.136 * *$ & 1 & 7.88 & 2.76 \\
\hline
\end{tabular}

** Sig. at .01 level, ${ }^{*}$ Sig. at .05 level 
Results above show that there were no significant relationships between Reading Comprehension of Students and Gender( $(\mathrm{r}=-.012 \mathrm{P}(.794)>.05)$, Age $(\mathrm{r}=.015 \mathrm{P}(.755)>.05)$, Marital Status( $\mathrm{r}=.024, \mathrm{P}(.608)>.05)$, Level of study $(\mathrm{r}=-.089 \mathrm{P}(.061)>.05)$ and Occupation $(\mathrm{r}=-.064 \mathrm{P}(.176)>.05)$.

\section{Discussion of Finding}

The study shows that the respondents genders rate is (61.6) for male and (38.4) for female. This shows that the reading habits and comprehension are key factors affecting not only the male undergraduates but theft female counterparts as well.

The study also observes that $(9.8 \%)$ of the respondents were aged $10-19$ years, $(80.2 \%)$ were aged 20 $29,(7.8 \%)$ were aged $30-39,(2.0 \%)$ were aged $40-49$ years, while $(2 \%)$ was above 50 years. Results on respondents marital status shows that $(86.0 \%)$ were single, $(12.0 \%)$ were married, $(7 \%)$ were divorced while $(1.3 \%)$ were widowed.

The level of respondents had 300 level with the highest response rate of (52.2\%), and 200 level having (3 6.2\%), with 400 level having (9.1\%), 100 level having the least respondents of (2.4\%). If this trend continues, especially with the rapidly increasing tendencies of bad reading habits and comprehension, most undergraduate students stand the risk of performing poorly academically. From the result $(16.7 \%)$ did not respond about their occupation. ( $1.8 \%)$ were fanners, $(2.2 \%)$ were traders, $(2.7 \%)$ were civil servants, $(1.1 \%)$ were Artisans, $(1.1$ $. \%)$ were policemen and soldiers while $(84.4 \%)$ were students.

The implication of this result is that students who were only students without jobs or skills to divert their attention still have bad reading habits and ability to comprehend.

\section{Summary/Conclusion}

The study investigated demographic factors as determinant of reading habits and comprehension of undergraduate students in their use of library resources in Benue state University, Makurdi. Based on the analysis in the preceding pages, the following conclusion was reached that there is no significant joint effect of independent variables of (Gender, age, marital status, level of study and occupation) on reading habits of students.

\section{References}

[1]. Aina, A. J., Ogungbeni, J. I., Adigun, J. A. and Ogundipe, T. C. 2011. Poor Reading habits among Nigerian: the role of libraries. Library Philosophy and Practice (e-journal) Paper 529. Retrieved March 23 , 2012 fromhttp://digitalcommons.unl.edu/libphilprac/529

[2]. Bray, K and Hasan, A. 2000. Reading habits and attitude in the digital age: Analysis of gender and academic program differences in Malaysia. The Electronic Library. $25 \quad$ (3), $285 \quad-\quad 298$. Retrieved January 6, 2013 from http://www.emeraldinsight.com/10.1108/02640470710754805

[3]. Hill Strategies Research, 2008. Factors in Canadians' Cultural Activities. Statistical Insights on the Arts, Vol. 6 No. 3 : Retrieved from: http://www.hillstrategies.com

[4]. Hopper, R. 2005. What are teenagers reading? Adolescent fiction reading habits and reading choices. Literacy 39.3: 113-120. Retrieved January 21, 2012 fromhttp://www.blackwellsynergy.com/doi/pdf/10.1111/j.14679345.2005.00409.x?cookieSet=1

[5]. Issa, A.O., Aliyu, M.B., Akangbe, R.B. and Adedeji, A.F. 2012. Learning which starts right from birth entails acquiring knowledge about various phenomena and understanding them. The more a person reads, the more he learns. International Journal of Learning \& Development. Vol. 2, No.1 Pp.470-486. Retrivend from: www.macrothink.org/ijld, accessed on: 01/03/2013, 11:44pm.

[6]. Kolawole, C.O.O. 2005. The state of reading in some selected secondary

[7]. schools in South Nigeria: A preliminary report. Issues in Language, Communication and Education: A Book of Readings in Honour of Caroline A. Okedara. Ibadan:

[8]. Lone, F. unl A. 2011. Reading Habits of rural and Urban College Students in

[9]. the $21^{\text {st }}$ century". Library Philosophy and Practice (e-journal) Paper 586. Retrieved March 29, 2012 from http://digitalcommons..edu/libphilprac/586

[10]. National Institute of Child Health and Human Development. 2000. Age-Related Changes in Reading and Oral Language Comprehension, Rockville PikeBethesda, Maryland

[11]. Sturm, Brian W.( 2003). The information and reading preferences of North Carolina children. School Library Media Research 6. Retrieved from:www.ala.org/ala/aasl/aaslpubsandjournals/slmrb/slmrcontents/volume62003/... accessed January 17.

[12]. Tor-Akwer, Helen F. (2013) Demographic factors as determinants of undergraduate reading habits in their use of library resources. M.Sc. Dissertation, University of Ibadan.

[13]. Toit, C. M.( 2001). The recreational reading habits of adolescent readers: A case study. Masters Dissertation. University of Pretoria. South Africa. 